\title{
VISCEROCUTANEOUS FORM OF LOXOSCELISM AND ERYTHROCYTE GLUCOSE-6-PHOSPHATE DEFICIENCY
}

\author{
Orlando G. O. BARRETTO (1), João Luiz GARDOSO (2) and Domingos De GILLO (2)
}

\section{S U M M A R Y}

In a period of time of five years, all patients who exhibited viscerocutaneous form of loxoscelism were investigated for erythrocyte glucose-6-phosphate deficiency, and in two patients out of seven it was found this deficiency. This finding suggests that this genetical enzyme deficiency could account for the hemolysis after loxosceles bite, at least in some of the cases.

\section{N T R O D U C T I O N}

Loxoscelism is a disease caused by the spider Loxosceles sp.bite. The human symptomatology of loxoscelism presents two clinical variants: 1) The cutaneous form. 2) The viscerocutaneous form. The cutaneous form of loxoscelism is the most commonly observed and develops very painful local edema and or local skin necrosis. The viscerocutaneous form is much more serious and occurs, according to SCHENONE \& SUAREZ 22, in an average of $13 \%$ of the total cases of loxoscelism. Besides exhibiting local manifestations identical to those seen in the cutaneous form, this clinical variant is composed of hemolytic anemia, jaundice, fever and sensorial involvement usually appearing within the first 6 to 24 hours after the bite. The utmost symptom accompanying this picture is the hemolytic anemia, which may induce to hemoglobinuria and occasional oliguria and anuria $5,8,17,18,20,24$.

The fact that only $13 \%$ of the cases develop hemolysis lead to the assumption of a possible susceptibility of these individuals. Certainly this greater susceptibility would not be caused by environmental factors, but it would be feasible to relate it to constitutive factors, to genetic factors. These constitutive factors would be represented by the lacking of genetically determined protective mechanisms or by the presence of a predisposition factor. This last hypothesis could be represented by the erythrocyte glucose-6-phosphate dehydrogenase deficiency. This deficiency is a very common genetic polymorphism, with high prevalent rates in several populations 1,3 . The G-6-PD deficient individual would develop the hemolytic crisis after a loxosceles bite. In this paper we have searched for glucose-6-phosphate dehydrogenase deficiency in all patients who developed hemolytic crisis in loxoscelism, in a period of five years in Instituto Butantan, São Paulo, Brazil.

\section{MATERIAL AND METHODS}

The clinical and laboratory data are summarised below:

1. Case M. L. - A white boy 10 years old was referred to Hospital Vital Brasil 8 hours after a bite in the costal region, presenting a very painful lesion, fever of $38^{\circ} \mathrm{C}$ and vomiting. He was interned and he was given 10 ampoules of anti-loxosceles serum, injected subcutaneously. The next day, he showed jaundice and dark urine. The spider was classified as Loxosceles gaucho. Laboratory data: hemoglobin: $11.0 \mathrm{~g} / \mathrm{dl}$; di-

Trabalho realizado no Laboratório de Pesquisas Hematológicas, Faculdade de Medicina da Universidade de São Paulo e Hospital Vital Brasil, Inst:tuto Butantan

(1) Prof. Livre-docente de Hematologia da Faculdade de Medicina U.S.P., Brazil

(2) Miédico do Fiospital Vital Brasil, do Instituto Butantan. São Paulo, Brazil 
BARRETTO, O. C. O.; CARDOSO, J. L. \& De CILLO, D. - Viscerocutaneous form of loxoscelism and erythrocyte glucose-6-phosphate deficiency. Rev. Inst. Med. trop. São Paulo 27:264-267, 1985.

rect bilirubin: $0.58 \mathrm{~g} / \mathrm{dl}$; indiret bilirubin: $2.35 \mathrm{mg} / \mathrm{dl}$; he was considered cured 7 days after and he was discharged in good condition.

2. Case J.B.S. - A white boy 13 years old was referred to Hospital Vital Brasil two days after a bite in his left ear, by an unidentified insect. The boy declared that 12 hours after the accident he felt very bad and the urine turned dark. He was given 12 ampoules of anti-loxosceles serum, sub-cutaneously. The laboratory data showed: hemoglobin: $5.8 \mathrm{~g} / \mathrm{dl}$; direct bilirubin: 0.6 $\mathrm{mg} / \mathrm{dl}$; indirect bilirubin: $2.4 \mathrm{mg} / \mathrm{dl}$; creatinine: $2.3 \mathrm{mg} / \mathrm{dl}$; BUN: $62 \mathrm{mg} / \mathrm{dl}$. He 'was heavily hydrated, being discharged 16 days after.

3. Case J.P.L.F. - A white boy 11 years old was examined at Hospital Vital Brasil 24 hours after a spider bite on the left thigh. At Hospital he exhibited painful edematoursechymotic lesion, besides jaundice, dark urine and oliguria. He was given 10 ampoules of anti-loxosceles serum sub-cutaneously. The laboratory data showed: hemoglobin: $6.7 \mathrm{~g} / \mathrm{dl}$; direct bilirubin: $1.4 \mathrm{mg} / \mathrm{dl}$; indirect bilirubin: $3.6 \mathrm{mg} / \mathrm{dl}$. After 18 days of adequate hydration, he could be discharged.

4. Case C.D.C. - A white boy 6 years old was referred to Hospital Vital Brasil two days after a bite on the left arm by an unidentified insect, in bad state, presenting jaundice and hemoglobinuria. The local lesion was typical of loxosceles bite, i.e., very painful with necrotic area and multiple ecchymosis. 10 Ampoules anti-loxosceles serum was given intravenously. Laboratory data showed: hemoglobin: $9.1 \mathrm{~g} / \mathrm{dl}$; BUN: $57 \mathrm{mg}$ ' $\mathrm{dl}$; direct bilirubin: $0.7 \mathrm{mg} / \mathrm{dl}$; indirect bilirubin: $2.9 \mathrm{mg} / \mathrm{dl}$; creatinine: $1.0 \mathrm{mg} / \mathrm{dl} ; 16$ days after he was discharged in good condition.

5. Case G.S. - A white woman 42 years was interned at the Hospital seven days after a bite on the right thigh. She had not seen the animal. She exhibited ecchymotic necrotic lesion on her right-thigh as well as slight jaundice. The laboratory data revealed: hemoglobin: $9.1 \mathrm{~g} / \mathrm{dl}$; direct bilirubin: $0.6 \mathrm{mg} / \mathrm{dl}$; indirect bilirubin: $2.35 \mathrm{mg} /$ dl. Three days after she was discharged without symptoms.
6. Case G.C.M. - A white man 39 years old was referred to Hospital Vital Brasil 7 hours after having been bitten in the right shoulder by a small spider which was killed afterwards and neglected. He presented. scarlatiniform exantema, fever, and an ecchymotic edematous lesion with central vesicle. He was given 10 ampoules of antiloxosceles serum sub cutaneously. The day after he bite, jaundice and dark urine were noticed. The laboratory data showed: hemoglobin: $13.1 \mathrm{~g} / \mathrm{dl}$; direct bilirubin: $0.6 \mathrm{mg}$ / $\mathrm{dl}$; indirect bilirubin: $2.9 \mathrm{mg} / \mathrm{dl}$. Three days after the bite, he was well and could be dis. charged.

7. Case J.D.S. - A white mulatto, 19 years old was seen at Hospital Vital Brasil 24 hours after having been bitten in the right shoulder by a small spider which was killed and neglected. She exhibited jaundice, exantema, dark urine, and $38,5^{\circ} \mathrm{C}$ fever. He was given 110 ampoules of anti-loxosceles serum sub-cutaneously. The laboratory data revealed: hemoglobin: $7.5 \mathrm{~g} / \mathrm{dl}$; direct bilirubin: $0.8 \mathrm{mg} / \mathrm{dl}$; indirect bilirubin: $4.0 \mathrm{mg}$ / dl; BUN: $106 \mathrm{mg} / \mathrm{dl}$. The patient was hydrated, and seven days after the bite he was discharged cured.

Blood was collected by venous puncture in ACD, kept at $4^{\circ} \mathrm{C}$, and the enzyme assays were performed within 4 to 5 days. The red cells were washed in saline at $4^{\circ} \mathrm{C}$, hemolysed in deionized water and centrifuged at $15.000 \mathrm{~g}$. The glucose-6-phosphatě dehydrogenase activity was done in the supernatant according to BEUTLER ${ }^{2}$, in Gilford 2451 recording spectrophotometer at $37^{\circ} \mathrm{C}$.

\section{RESULTS}

The glucose- 6 phosphate dehydrogenase activities are shown in Table $I$.

\section{DISCUSSION}

The pathogenesis of hemolysis in loxosceles envenomation has been exaustively studied in the last years, but it has been facing great pro. blems, as the determination of its chemical structure. SUAREZ et al. ${ }^{21}$ suggested a glycoprotein nature for the component of $\mathbf{L}$. laeta venom, and at least two toxic fractions were separated by ODELL et al. ${ }^{18}$. Some enzymes have been 
BARRETTO, O. C. O.; CARDOSO, J. L. \& De CILLO, D. - Viscerocutaneous form of loxoscelism and erythrocyte glucose-6-phosphate deficiency. Rev. Inst. Med. trop. São Paulo 27:264-267, 1985.

T A B I E I

Erythrocyte glucose-6-phosphate dehydrogenase (G-6-PD) activity in hemolytic form of loxoscelism

\begin{tabular}{|c|c|c|}
\hline \multirow[t]{2}{*}{ Patients } & \multicolumn{2}{|r|}{ G-6-PD } \\
\hline & i.u. $/ g$ & $\mathrm{Hb} / \min / 37^{\circ} \mathrm{C}$ \\
\hline Normals & 12.12 & $\pm 2.09(02)$ \\
\hline M.L. & & 11.0 \\
\hline J.B.S. & & 18.4 \\
\hline J.P.X.F. & & 11.3 \\
\hline C.D.C. & & 10.2 \\
\hline G.S. & & 4.8 \\
\hline G.C.M. & & 10.1 \\
\hline J.D.S. & & 5.3 \\
\hline
\end{tabular}

described in extracts of the venoms of some species, but not linked to the toxic fractions. Thus, the enzymes adenosine triphosphatases 21 , hialuronidase ${ }^{4}$ were found in L. laeta, and alka. line phosphatase ${ }^{11}$, esterase and hialuronida. se $^{24}$, lipase ${ }^{16}$, protease ${ }^{24}$ in $\mathbf{L}$. reclusa, although GEREN et al. ${ }^{9}$ did not find protease activity in this last specie.

The proteases could be a red cell lytic factor, but the contradictory data obtained do not help to keep up this hypotesis. The phospholipases $A, C$ and $D$ which could account for the hemolytic process were not found in L. laeta and L. reclusa 10,16,21. The hyaluronidase would have a predisposition role in venom penetration in the tissues, but not in hemolysis ${ }^{24}$. KNIERIM et al. ${ }^{12}$ noticed that the venom itself did not cause hemolysis in vitro in red cells of several species, but abdominal wall, hemolymph, abdominal content, eggs and cephalo-torax extracts did lead to hemolysis.

An hypothesis to be considered would be the activating effect on the complement, which leads to hemolysis. The importance of hemolytic serum complement was first suggested by KNIKER \& MORGAN ${ }^{13}$, and KNIKER et al. ${ }^{14}$. They were able to show that very small amounts of brown recluse spider venom interacted with complement. Further studies ${ }^{6}$ demonstrated that venom reacted with several of the components of human complement and anactivated them. MORGAN et al. ${ }^{15}$ have shown that washed human erythrocyte were altered in the presence of small quantities of venom in such a way that subsequent addition of fresh and non heat inactivated blood group compatible serum lead to lysis. FUTRELL et al. ${ }^{7} \mathrm{sub}$ sequently developed a quantitative hemolytic test based on this observation. They verified that hemolysis was quantitatively related to individual sera rather than to differences in erythrocytes and also noticed that swine erythrocytes behave as human ones. This was not observed in rabbit, guinea pig and dog erythrocytes. BIGGEMAN ${ }^{4}$ verified that rats (Rattus norvegicus) did not present any venom serum inhibitor, and demonstrated that the venom binds strongly to the human erythrocyte membrane.

So, there are many doubts and few certainties on the pathogenesis of the hemolysis in Loxoscelism. As hemolysis occurs in a minute percentage of all cases, genetic factors could account for this tendency, and this hypothesis is stronly supported by the fact that venom does not lead to hemolysis in all mammals. Among the possible genetic factors the presence of a venom inborn inhibitor which would be absent or decreased in some individuals could be considered. Another hypothesis would be a genetic deficiency of a protective enzyme, in such a way that the deficiency individual would develop hemolysis when in contact with the venom.

The role of glucose-6-phosphate dehyarogenase (G-6-PD) deficiency in the pathogenesis of hemolysis was first investigated by NANCE 16 , who found normal levels of activity enzyme in one tested patient who inhibited a hemolytic form of loxosceles. On our series, we studied 7 patients with a viscerocutaneous type of loxoscelism, and we could detect 2 out of them with G-6-PD deficiency. The mechanism of hemolysis in G-6-PD deficiency seems to be related to an oxidative effect of a group of chemicals, as sul. phonas and sulphonamides, primaquine and related compounds, nitrofurantoins, bacterial or virotic infections ${ }^{3}$. In loxoscelism, the hemo. lysis in some patients could be related to an oxidant substance present in the venom. Al. though we had in five years only seven cases, what does not allow for an analysis with statistical purposes, it could suggest that the G-6-PD deficiency would be another factor, among others, leading to hemolysis in some in dividuals.

\section{RESUMO}

Forma viscerocutânea de loxoscelismo e defi. ciência de glicose-6-fosfato desidrogenase

Em um período de cinco anos, todos os pacientes que exibiram a forma viscerocutânea do 
BARRETTO, O. C. O.; CARDOSO, J. L. \& De CILLO, D. - Viscerocutaneous form of loxoscelism and erythrocyte glucose-6-phosphate deficiency. Rev. Inst. Med. trop. São Paulo 27:264-267, 1985.

loxoscelismo foram investigados para a deficiência de glicose-6 fosfato desidrogenase eritrocitária, e em dois pacientes em um total de sete, esta deficiência foi encontrada. Este achado sugere que esta deficiência enzimática genétíca poderia ser uma das causas da hemólise que ocorre em decorrência da picada por Loxosceles.

\section{REFERENCES}

1. BARRETTO, O. C. O. - Erythrocyte glucose-6-phosphate dehydrogenase deficiency in São Paulo, Brasil. Rev. Brasil. Pesq. Méd. Biol. 3: 61-65, 1970.

2. BEUTLER, E. - Glucose-6-phosphate dehydrogenase. In: Red Cell Metabolism. A Manual of Biochemical Methods. 2nd ed. New York, Grune \& Stratton, 1975, 66-69.

3. BEUTLER, E. - Glucose-6-phosphate dehydrogenase deficiency. In: Hematology. Williams, W. J.; Beutler, E.; Erslev, A. J. \& Rundles, R. W. (Ed.). 2nd ed. New York, McGraw-Hill Book Co., 1977, 456-479.

4. BIGGEMANN, U. - Estudios bioquimicos del veneno de la araña L. laeta y su mecanismo de acción. [Thesis]. Chile, University of Concepción, 1971.

5. DELGADO, A. - Loxoscelism. I: Formas clinicas del sindrome cutaneo. Rev. Soc. Peruana Dermat. 3: 73 76,1969 .

6. FUTRELL, J. M. \& MORGAN, P. N. - Inhibition of human complement components by Loxosceles reclusa venom. Inter. Arch. Allergy Appl. Immun. 57: 275$278,1978$.

7. FUTRELL, J. M.; MORGAN, B. B. \& MORGAN, P. N. - An in vitro model for studying hemolysis asso. ciated with venoms from the brown recluse spider (Loxosceles reclusa). Toxicon 17: 355-362, 1979.

8. GAJARDO-TOBAR, R. - Mi experiencia sobre loxoscelismo. Mem. Inst. Butantan 33: 689-698, 1966.

9. GEREN, C. R.; CHAN, T. K.; WARD, B. C.; HOWELL, D. E.; PINKATON, K. \& ODELL, G. V. - Composition and properties of extract of fiddle back (Loxos. celes reclusa) spider venom apparatus. Toxicon 11: $471-479,1973$.

10. HALL, J. E. - A study of protein and peptide components of venoms of Loxosceles reclusa (getsch and Mulaik) and Dugesiella hentzi (Girard). [Masters Thesis]. Oklahoma State University, Stillwater, Oklahoma, 1970.

11. HEITZI, J. R. \& NORMENT, B. R. - Characteristics of an alkaline phosphatase activity in brown reciusa venom. Toxicon 12: 181-187, 1974 .
12. KNIERIM, F.; LETONJA, T. \& SCHENONE, H. Activated in vitro del veneno $\mathrm{y}$ otros componentes orgánicos de Loxosceles laeta sobre eritrocitos humanos y animales. Bol. Chil. Parasit. 30: 43-46, 1975.

13. KNIKER, W. T. \& MORGAN, P. N. - An inactivator in spider of the fifth component of complement. Fed, Proc. 26: 362, 1967.

14. KNIKER, W. T.; MORGAN, P. N.; FLANIGAN, W. J.; REAGEN, P. W. \& DILLAHA, C. J. - An inhibitor of complement in the venom of the brown recluse spider, Loxosceles reclusa. Proc. Soc. Exper. Biol. \& Med. 131: 1432-1434, 1969.

15. MORGAN, B. B.; MORGAN, P. N. \& BOWLING, R. E. - Lysis of human erythrocyte by venom from the brown recluse spider, Loxosceles reclusa. Toxicon 16: 85-88, 1978.

16. NAZHAT, N. - Venom of Loxosceles reclusa: protein components. [Masters Thesis]. Oklahoma State University, Stillwater, Oklahoma, 1968.

17. NANCE, W. E. - Hemolytic anemia of necrotic arachnidism. Amer. J. Med. 31: 801-807, 1961.

18. ODELL, G. V.; CHAN, T. K.; GEREN, C. R.; LEE, C. K.; WARD, B. C. \& HOWELL, D. E. - Chemical and biological properties of tarantula and brown re. clusa venom toxins. Fed. Proc. 34: 504, 1975.

19. REID, H. A. - Venomous bites and stings. Trop. Doctor 5: 12.19, 1975.

20. SCHENONE, H.; RUBIO, S.; VILLARROEL, F. \& ROJAS, A. - Epidemiología y curso clinico del loxoscelismo. Estudio de 133 casos por la araña de los rincones (Loxosceles laeta). Bol. Chil. Parasit. 30: 6-17, 1975.

21. SUAREZ, G.; BIGGEMANN, U. \& SCHENONE, H. Estudios bioquimicos del veneno de Loxosceles laeta y de sus mecanismos de acción. Bol. Chil. Parasit. 26: 60-62, 1971.

22. SCHENONE, H. \& SUAREZ, G. - Venoms of Schystodidae. Genus Loxosceles. In: Handhook of Experimental Pharmacology 48: 247-275, 1978. (Heffer-Heubner - New Series Springer Verlag). Berlin, Heilderberg, New Yorik.

23. TAYLOR, E. H. \& DENNY, W. F. - Hemolysis, renal failure and death, presumed secondary to bite of brown recluse spider. Southern Med. J. 19: 1209-1211, 1966.

24. WRIGHT, R. P.; CAMPHELL, B. J. \& BARRETT, J. L. - Enzymatic characterization of Missouri brown spider venom. 164th ACS Meeting, New York (Abstr. 50), 1972.

Recebido para publicação em $31 / 8 / 1984$. 